Discussion Paper No. 09-002

Host Country Contingencies on Knowledge Protection Strategies of Multinational Firms Bring a Knife to a Gunfight?

Wolfgang Sofka and Edlira Shehu

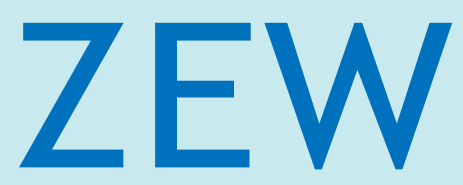

Zentrum für Europäische Wirtschaftsforschung $\mathrm{GmbH}$

Centre for European

Economic Research 
Discussion Paper No. 09-002

\title{
Host Country Contingencies on Knowledge Protection Strategies of Multinational Firms - Bring a Knife to a Gunfight?
}

\author{
Wolfgang Sofka and Edlira Shehu
}

Download this ZEW Discussion Paper from our ftp server:

ftp://ftp.zew.de/pub/zew-docs/dp/dp09002.pdf

Die Discussion Papers dienen einer möglichst schnellen Verbreitung von neueren Forschungsarbeiten des ZEW. Die Beiträge liegen in alleiniger Verantwortung der Autoren und stellen nicht notwendigerweise die Meinung des ZEW dar.

Discussion Papers are intended to make results of ZEW research promptly available to other economists in order to encourage discussion and suggestions for revisions. The authors are solely responsible for the contents which do not necessarily represent the opinion of the ZEW. 


\section{Non-technical Summary}

International knowledge spillovers through multinational companies (MNC) and their international subsidiaries have recently been a major topic of academic and management discussion. However, MNC are mainly treated as relatively passive actors without clear knowledge protection strategies. We expand this stream of research by explicitly investigating how MNC subsidiaries actively protect their knowledge by using legal as well as marketbased knowledge protection instruments. Whereas existing studies usually solely rely on legal knowledge protection instruments (patents, copyrights, trademarks) as indicators of knowledge protection, we additionally include market-based ones (secrecy, lead time, complex design), which are barely examined in existing literature. We argue that the choice and intensity of knowledge protection strategies is influenced by the technological development of the host country. Host country technological development is measured along two dimensions: geographical location and industry strength.

An empirical investigation of more than 1,500 German firms reveals that both dimensions provide important contingencies to MNC subsidiary managers. They differ, however, with regards to the type of knowledge protection. Legal forms are used more restrictively if the geographical subsidiary environment in the host country is technologically leading. We suspect that this is due to the fact that the dangers for knowledge outflows through personnel turnover are especially pressing in highly developed areas, as skilled employees have multiple employment opportunities without major distractions to their personal life. Market-based strategies, though, are used substantially less restrictively when the host country is a technological leader in the respective MNC industry. Demonstrated reciprocity in knowledge exchanges is apparently especially rewarding with technologically leading host country counterparts. Overly restrictive market-based protection strategies (e.g. through secrecy) may damage these relationships as they are designed to provide no signals to potential counterparts. In contrast, legal protection strategies imply a formal application process providing foreign MNC subsidiaries with tangible signals of their research activities for potential partners.

From a management perspective our results indicate that MNC subsidiaries need to develop knowledge protection strategies that go beyond patenting. Knowledge protection strategies have to reflect host country contingencies along two major dimensions: industry and geography. MNC subsidiaries require formal knowledge protection capabilities when they engage in geographically leading host country regions. Conversely, the budgets for developing and maintaining these capabilities can be limited in host country states or districts with lagging status. Technological opportunities for sourcing knowledge from host country competitors in the same industry require reciprocity with regards to market-based protection strategies. Hence, MNC subsidiary management should be prepared to actively engage in host country knowledge sharing once opportunities arise. In lagging host country industry environments, though, they should increase the restrictiveness these protection mechanisms. 


\section{Das Wichtigste in Kürze (Summary in German)}

Internationaler Wissenstransfer durch multinationale Unternehmen (MNU) und ihre internationalen Niederlassungen hat besondere Aufmerksamkeit im aktuellen akademischen und praxeologischen Diskurs gefunden. Obwohl die Rolle von MNU als Multiplikator in Wissenstransferprozessen ausgiebig erforscht ist, existieren kaum Befunde darüber, wie MNU aktiv den Abfluss von Wissen im Ausland zu verhindern versuchen. MNU werden häufig als eher passive Akteure ohne klare Wissensschutzstrategie betrachtet. Die vorliegende Analyse knüpft an bestehenden Befunden an und erweitern diese durch die Untersuchung des Einsatzes legaler (z.B. Patentierung) und marktbasierter Schutzstrategien (z.B. Geheimhaltung) von MNU-Managern. Während im bisherigen Studien hauptsächlich so genannte legale Schutzinstrumente berücksichtigt werden, welche meistens durch Patente als alleinigen Indikator operationalisiert werden, untersucht die vorliegende Arbeit zusätzlich den Einsatz markt-basierter Instrumente, die in bisheriger Forschung kaum explizite Betrachtung gefunden haben. Hypothesen über die Wahl und Einsatzintensität der legalen und marktbasierten Schutzstrategien der MNU in Abhängigkeit der technologischen Führerschaft ihres externen Standortes werden in dieser Studie entwickelt. Dabei wird auf der einen Seite die technologische Führerschaft des geographischen Standortes und auf der anderen Seite diejenige der operierenden Branche der MNU berücksichtigt.

Eine empirische Analyse an einer aus mehr als 1500 deutschen Firmen bestehenden Stichprobe unterstützt die Hypothesen. Die Ergebnisse zeigen Unterschiede zwischen den inländischen Unternehmen und MNU hinsichtlich der eingesetzten Wissensschutzstrategien. MNU setzen legale Wissensschutzinstrumente häufiger ein, wenn die geographische Landschaft des externen Standortes den Status eines Technologieführers hat. In solchen Fällen ergeben sich vielfältige Beschäftigungsmöglichkeiten für kompetente Mitarbeiter, welche wertvolles Wissen zu potenziellen Wettbewerbern transferieren können. Im Gegensatz hierzu werden markt-basierte Strategien weniger restriktiv eingesetzt, wenn der externe Standort eine technologische Führerschaft hinsichtlich der Branche, in der das MNU aktiv ist, aufweist. Signalisierte Reziprozität im Wissenstransfer mit potenziellen Kooperationspartnern scheint aus Sicht von MNU profitabel zu sein, während restriktive Schutzstrategien schädlich sein könnten, da diese mangelhaftes Kooperationsinteresse signalisieren können.

Die Ergebnisse zeigen, dass MNU sowohl legale als auch markt-basierte Wissensschutzstrategien entwickeln und einsetzen sollen. Beide Strategien sollten sich an der technologischen Landschaft des externen Standortes anhand zweier Dimensionen, geographisch und branchenbezogen, orientieren. Legaler Wissensschutz gewinnt an Relevanz, wenn der externe Standort den Status eines technologischen Führers aus geographischer Sicht besitzt. Damit verbundene Investitionen können auf der anderen Seite eingespart werden, wenn der geographische Standort technologisch unterentwickelt ist. Wissenstransfer mit den Wettbewerbern des externen Standortes erfordert jedoch Reziprozität hinsichtlich der marktbasierten Strategien. Vor diesem Hintergrund sollte das Management von MNU in solchen Umfeldern aktiv an Kooperationsprojekten teilnehmen. Restriktive Schutzmechanismen sind die richtige Strategie für MNU-Niederlassungen, wenn das technologische Umfeld im Gastland unterentwickelt ist. 


\title{
Host Country Contingencies on Knowledge Protection Strategies of Multinational Firms - Bring a Knife to a Gunfight?
}

\author{
Wolfgang Sofka ${ }^{1}$ and Edlira Shehu ${ }^{2}$ \\ ${ }^{1}$ ZEW Centre for European Economic Research, Mannheim, Germany \\ ${ }^{2}$ University of Hamburg, Germany
}

\begin{abstract}
International knowledge spillovers, especially through multinational companies (MNCs), have recently been a major topic of the academic and management discussion. However, most studies treat MNC subsidiaries as relatively passive actors without clear knowledge protection strategies. The goal of this study is to extend this stream of research by investigating both market-based (e.g. secrecy, lead time) as well as legal knowledge protection strategies (e.g. patents, trademarks) of MNC subsidiaries. We argue that these strategies are not independent from the opportunities and challenges of the host country. We suggest that the host country leadership status influences the choice of knowledge protection strategies along two major dimensions: geographical and industry strength of host country firms. We test our hypotheses for a broad sample of more than 1,500 firms in Germany. The results indicate that legal forms of knowledge protection are used more restrictively if the host country geographical environment is technologically leading while technological leadership of host country competitors within the industry leads to less restrictive market-based knowledge protection strategies. We develop management recommendations based on these trade-offs between reliable knowledge protection and the need for reciprocity in exchanging knowledge.
\end{abstract}

Keywords: Knowledge protection, Multinational Companies, Patenting

JEL-Classification: F23, O31, O32, D8

Corresponding author:

Wolfgang Sofka

Sofka@zew.de

Phone: +49/621/1235-181, Fax: +49/621/1235-170

ZEW Centre for European Economic Research

Department of Industrial Economics and International Management

P.O. Box 1034 43, D-68034 Mannheim, Germany

We thank Christian Rammer for invaluable comments and discussions. We are especially indebted to Christoph Grimpe for generously sharing data with us. 


\section{$1 \quad$ Introduction}

The development of new knowledge and technologies is globally concentrated in relatively few countries. Although a small number of countries, such as South Korea, have been very dynamic in their knowledge production in recent years (Furman and Hayes, 2004; Mahmood and Singh, 2003) still $80 \%$ of all R\&D expenditures remain concentrated in the seven most industrialized countries (G7) in 2005 which is only slightly down from the $84 \%$ ten years earlier (Keller, 2004; OECD, 2007). Hence, international knowledge transfer becomes crucial for global growth (Romer, 1990). One of the most promising channels for facilitating these knowledge spillovers are Multinational Corporations (MNCs) and their network of international subsidiaries. Their advantages for border-spanning knowledge transfers have been conceptualized in several ways, such as the internalization of transaction costs (e.g. Buckley and Casson, 1981), differentiated networks that provide a fit with varying environmental and resource contingencies (e.g. Goshal and Bartlett, 1990) or social communities spanning borders (e.g. Kogut and Zander, 1993).

The effects of these engagements have been the subject of intense academic debate. Much research in international economics has focused on MNC's potential to transfer knowledge to the host country (see for example Aitken and Harrison, 1999; Haskel et al., 2007; Keller, 2002). In contrast, international business literature emphasizes the role of subsidiaries for accessing knowledge from host countries (see for example Almeida, 1996; Frost, 2001). However, only a relatively recent stream of literature focuses on the active knowledge protection strategies of MNCs to prevent their knowledge from spilling over host country competitors (Alcacer and Chung, 2007; Zhao, 2006).

We extend this stream of research by investigating a broad spectrum of MNC knowledge protection strategies. These go beyond legal instruments, like patents which are used in most of the research studies as the only indicator of knowledge protection, and include marketbased instruments, like secrecy, lead time and complex design. Beyond investigating the importance of legal versus market-based knowledge protection strategies of MNCs, we argue that these strategies are not independent from the opportunities and challenges of the host country. We develop hypotheses for the moderating effect of host country contingencies on the choice and impact of knowledge protection strategies for MNCs. More precisely, by using R\&D indices which indicate the technological leadership of a) MNC subsidiary's industry and b) its host country location we tie up to findings of existing research and enrich it by suggesting that host country industry and location specific technological leadership play an important role in the choice of knowledge protection strategies. We test these hypotheses empirically for a broad sample of more than 1,500 firms in Germany.

The paper is structured as follows. Section 2 presents our theoretical framework and the derivation of hypotheses based on this discussion. Section 3 presents the empirical study, which results are presented in section 4 . We discuss them in section 5, draw conclusions and suggest some pathways for future research in section 6 . 


\section{Theoretical framework}

\subsection{Literature review}

The goal of this section is to connect the literature on knowledge protection with the specific opportunities and challenges for MNC subsidiaries abroad. Knowledge spillovers to the host country from MNC subsidiaries (see for example Haskel et al., 2007; Keller, 2002) and vice versa (see for example Almeida, 1996; Frost, 2001) have received much attention in academic discussion. However, the particular topic of knowledge protection strategies by MNC subsidiaries has largely been neglected in international business literature so far (with the notable exceptions of Alcacer and Chung, 2007; Shaver and Flyer, 2000; Zhao, 2006).

Several important studies on MNCs and international knowledge spillovers have treated patenting - the most prominent form of knowledge protection - as an indicator of knowledge production and related patent citations as traceable knowledge flows (e.g. Almeida and Phene, 2004; Jaffe and Trajtenberg, 1999; Porter and Stern, 2000). Most research examining international knowledge spillovers from MNCs (for a review see Keller, 2004) assign a rather passive role to MNC subsidiaries when it comes to managing or preventing outgoing knowledge spillovers.

A growing stream of research emphasizes the role of knowledge protection for MNCs and their network of international subsidiaries. Several studies find that MNCs respond positively to stricter IPR enforcement in host countries (Branstetter et al., 2006; Ito and Wakasugi, 2007). However, relatively little is known on how managers of MNC subsidiaries design their knowledge protection strategies. Alcacer and Chung (2007) show that MNC subsidiaries consider outgoing knowledge spillovers in their host county location choices. They demonstrate for international MNC entrants to the US market that firms expecting to benefit from ingoing knowledge spillovers locate close to US industry activity while those afraid of outgoing spillovers avoid them. Zhao (2006) shows for the case of China that MNCs choose to perform particular $R \& D$ activities in host countries with weak intellectual property rights (IPR) regimes which outputs are only valuable when combined with competitive assets protected in other countries with stronger IPR protection. Our goal is to extend this stream of research by going beyond location decisions and the complex organization of distributed R\&D activities. We focus on the broader knowledge protection strategies of MNC subsidiary managers and relate them to host country contingencies.

Knowledge protection is an important element of appropriating the returns from a firm's investment in developing new products, processes or services (see for example Rivette and Kline, 2000). Unique knowledge is the most valuable resource of a firm as it enables them to develop, deploy and discard all other resources (Grant, 1996). However, knowledge is by its very nature a public good in the sense that it can easily spill over to competitors and enable them to imitate the innovative firm without investing into knowledge production (Adams and Jaffe, 1996; Nadiri, 1993). Firms have therefore strong incentives to protect their knowledge and prevent it from spilling over. Management may choose between legal knowledge 
protection strategies (such as patenting) and market-based ones (such as secrecy) (Encaoua et al., 2006). ${ }^{1}$

Legal forms of knowledge protection imply that knowledge is protected by intellectual property laws and infringements can be punished in court (Teece, 1998). Patenting is the most prominent element of this category granting exclusive usage rights to an invention for a certain period of time (Arrow, 1962). Other types of legal knowledge protection include the registration of industrial designs, trademarks and copyrights (Laursen and Salter, 2005). The latter do not grant rights for exclusive usage but a replication monopoly for its owner (Porter Liebeskind, 1997). Characteristic to legal knowledge protection methods is a formal application process for protection at a government agency (e.g. patent office). This process usually requires substantial investment in terms of time, resources and specialized expertise (e.g. consulting from lawyers). Legal protection is most applicable for established knowledge which can be codified and embodied in final products or services (Saviotti, 1998). Patenting has been found to be especially relevant for certain firms and industries. Firms with patents are typically larger, engage in $R \& D$ activities and operate in knowledge intensive sectors, especially pharmaceuticals, chemicals and machinery/equipment (Arundel and Kabla, 1998; Brouwer and Kleinknecht, 1999). The effectiveness of patenting for knowledge protection has been questioned as competitors may benefit from the knowledge disclosed in the patent itself which enables them to "invent around it", i.e. circumvent central parts of the protection through alternative technological approaches (see for example Mansfield, 1986; Mansfield et al., 1981). Nevertheless, legal methods of knowledge protection allow managers to receive tangible representations of their investments into the production of intangible knowledge. Hence, the value of patents does not exclusively stem from protecting knowledge but also from signalling its value to investors or potential collaboration partners (Cohen et al., 2002; Cohen et al., 2000; Harabi, 1995).

Knowledge protection through market-based methods relies upon organizational processes aimed at preventing knowledge spillovers in the first place or limiting their negative effects. Existing research has primarily focussed on the following methods of market-based knowledge protection: secrecy, lead time, complex design as well as complementary assets in sales, marketing or production (Cohen et al., 2000; Harabi, 1995; Laursen and Salter, 2005). Secrecy requires restrictive sets of rules within the company limiting the transfer of knowledge to specified others, social interactions with them or restrict physical access to certain locations, e.g. laboratories (Porter Liebeskind, 1997). If these rules can be monitored and enforced effectively they provide efficient knowledge protection. This method has been found to be among the most important forms of knowledge protection for firms of all sizes and industries (Harabi, 1995). However, its effectiveness is also limited by personnel mobility as a channel for knowledge transfer to competitors (Arrow, 1962). Knowledge protection through lead time implies that firms can benefit from first mover advantages of being first to the market and exploiting the benefits before competitors can effectively challenge them through imitation (for a review see Lieberman and Montgomery, 1988). Complex design and

\footnotetext{
$1 \quad$ Other authors have suggested to call the market-based forms of knowledge protection (typically encompassing lead time, secrecy and complex design) as "strategic" or "first mover" and legal ones (primarily patenting, copyrights, industrial design trademarks) as "formal” (e.g. Harabi, 1995; Laursen and Salter, 2005). We stick with the terminology introduced by Encaoua et al. (2006).
} 
complementarities with other firm functions adds additional barriers to successful knowledge spillovers to competitors. It implies that knowledge is only valuable when replicated in a certain context which may be easier to control and protect for a firm (Teece, 1998). Complex knowledge is more difficult to transfer completely as it requires the simultaneous transfer of additional knowledge to reach its full potential (Szulanski, 1996). Market-based protection methods can be used for all sorts of knowledge even in the early, tacit stages (Saviotti, 1998).

\subsection{Hypothesis development}

The choice of legal versus market-based knowledge protection strategies has often been explained by the necessary resource commitments which make market-based ones more appropriate for smaller firms (Byma and Leiponen, 2006). However, this seems to be a less pressing concern for MNCs. Instead, we argue that their choice of knowledge protection strategy depends upon the knowledge that has to be protected. Porter Liebeskind (1997) points out that this is an important dimension of knowledge protection. She differentiates between codified vs. tacit knowledge, individual vs. collective knowledge, legally protectable vs. non-protectable knowledge and usable vs. unusable knowledge. All of these factors influence the likelihood and channels for potential outflows of knowledge which have to be addressed through protection strategies.

\section{Market-based versus legal knowledge protection methods of MNC subsidiaries}

We argue that market-based protection strategies are especially relevant for MNC's knowledge. Kogut and Zander (1993) envision an MNC as a social community with a shared understanding on the production and transfer of knowledge through repeated interaction. This capability enables MNCs to transfer knowledge effectively and efficiently between international subsidiaries. It is especially relevant for types of knowledge which are not codified or tacit in nature. These especially valuable pieces of knowledge can hardly be protected through legal protection methods. On the one hand, they require codification to be protected (Saviotti, 1998). The transferred knowledge is often just an "intermediate" good which will enter final products or services - which could be protected through legal methods in later stages of the innovation process (Teece, 1998). On the other hand, legal protection methods like patenting would imply that MNC subsidiaries disclose some of this valuable knowledge by applying for legal protection, e.g. through patents (Gallini, 2002). In conclusion, we argue that the unique opportunity for MNCs to transfer tacit and not codified knowledge effectively to foreign subsidiaries requires an adequate protection strategy. Market-based knowledge protection strategies are especially suitable to protect this particular type of knowledge (Saviotti, 1998). We hypothesize:

Hypothesis 1: Market-based knowledge protection methods are more important for MNC subsidiaries than legal ones for restricting outgoing knowledge spillovers. 


\section{The moderating role of host country opportunities and challenges in knowledge exchanges}

Additionally, we argue that MNC subsidiary management will choose the degree of restrictiveness of their knowledge protection strategies based on host country contingencies. We define the restrictiveness of a knowledge protection strategy through the variety and intensity of instruments used. A protection strategy encompassing multiple methods (e.g. secrecy and lead time) with high intensity would be considered more restrictive, i.e. allowing less outgoing knowledge spillovers. Our line of reasoning is built around the relationship between ingoing and outgoing knowledge spillovers. Both aspects are interconnected (Cassiman and Veugelers, 2002). Access to promising knowledge sources in the host country may require a certain amount of knowledge sharing, i.e. less restrictive protection strategies. Hence, we argue that MNC subsidiary managers will choose knowledge protection strategies based on host country consistencies.

On the one hand, more restrictive knowledge protection strategies appear appropriate in host counties where the likelihood of loosing valuable knowledge to competitors is high. The consequences of such spillovers depend crucially on the degree of the absorptive capacities of these host country competitors. Absorptive capacities encompass all competences and organizational processes for identifying, assimilating and exploiting knowledge from their environment (Cohen and Levinthal, 1989; 1990). These absorptive capacities are typically acquired by performing own R\&D activities and accumulating knowledge over time. Host countries with high $R \& D$ expenditures in a particular industry can therefore be expected to have domestic firms with high absorptive capacities. In such host countries MNC subsidiary management should opt for more restrictive knowledge protection strategies. In environments where this risk is low MNC subsidiary managers can opt for less restrictiveness and save scarce resources as all knowledge protection strategies entail certain costs, such as the legal advice for patent application or the monitoring of secrecy rules (Porter Liebeskind, 1997). We propose:

\footnotetext{
Hypothesis 2a: MNC subsidiary managers opt for more restrictive knowledge protection strategies (legal and market-based) in technologically advanced host country environments.
}

On the other hand, opportunities for knowledge spillovers from host country competitors have been identified as important incentives for MNCs to locate their subsidiaries in a particular country (Feinberg and Gupta, 2004) as well as within the host country (Alcacer and Chung, 2007; Shaver and Flyer, 2000). The latter authors find that MNCs locate their subsidiaries closer to industry activity in the host country if they expect to benefit from ingoing knowledge spillovers and farther away if they fear outgoing ones. Knowledge exchanges require stable channels and a mutual understanding over time (Laursen and Salter, 2006). They benefit from repeated interaction and mutual trust (Hakanson and Nobel, 2001). Trust can be defined as "a psychological state comprising the intention to accept vulnerability based upon positive expectations of the intentions or behaviour of another" (Rousseau et al., 1998: p. 395). MNC subsidiary management engaging actively in knowledge sharing by accepting certain vulnerabilities through knowledge disclosure may compensate it with valuable ingoing spillovers in the future. Literature defines these positive expectations as 
reciprocity mechanisms: "voluntarily repaying a trusting move at a later point in time, although defaulting on such repayment is in the short-term self interest of the reciprocator" (Gunnthorsdottir et al., 2002, p. 50). We derive:

Hypothesis 2b: MNC subsidiary managers opt for less restrictive knowledge protection strategies (legal and market-based) in technologically advanced host country environments.

The relevant host country environment for in- and outgoing knowledge spillovers can be defined along industry as well as geographical dimensions. Lane and Lubatkin (1998) find that knowledge flows benefit from technological congruence between knowledge sources and recipients. Knowledge recipients find it easier to assess the relevance of the potential knowledge flow since it has been produced in a similar technological context. This shared context reduces the necessary costs for transforming the external knowledge before it can be absorbed and assimilated with existing knowledge stocks (Todorova and Durisin, 2007). Intra-industry spillovers can therefore be considered to be especially relevant for MNC subsidiaries. Hence, they may determine their choice of knowledge protection strategies. We hypothesize:

Hypothesis 3: The technological leadership status of the host country industry environment determines MNC subsidiary manager choices on knowledge protection strategies.

Knowledge spillovers have been found to be confined to relatively narrow geographical areas (e.g. Audretsch and Feldman, 1996). The effectiveness of knowledge transfers decreases significantly with the distance between source and recipient. This limitation has been explained through cultural, language and institutional differences across national borders but also within countries (Jaffe et al., 1993; Peri, 2005). Other authors have highlighted the limited mobility of skilled engineers and scientists (Almeida and Kogut, 1999). This perception considers personnel turnover as the primary channel for knowledge spillovers. The geographical concentration of knowledge spillovers can therefore be explained through the unwillingness of its carriers to move. We conclude:

Hypothesis 4: The technological leadership status of host country geographical environment determines MNC subsidiary manager choices on knowledge protection strategies.

\section{$3 \quad$ Data and Methods}

\section{Sample}

For testing our hypotheses we use data from the fourth European Community Innovation survey (CIS-4) for more than 1,800 firms and their innovation behaviour in Germany in 2005. The survey is directed at the heads of $R \& D$ departments or innovation management and comprises data on the innovation activities of firms from manufacturing as well as service sectors. Developed under the guiding principles of the Oslo Innovation Manual, the survey aims at collecting data on innovation understood from a broad firm perspective (OECD, 
1992). Since most of the questions in the survey have to be answered only by innovative firms, i.e. firms that have introduced at least one product or process innovation between 2002 and 2004 we restricted our sample to this group of firms. The sample is stratified by region (East and West Germany) in addition to size and industry to account for the effects of reunification. Roughly $10 \%$ of the firms in the sample are foreign subsidiaries.

Heads of R\&D departments or innovation management are asked directly if and how their firms are able to generate innovations. This leads to the production of direct measures for innovation processes and outputs which can complement traditional measures of innovation activity such as patents (Kaiser, 2002; Laursen and Salter, 2006). Moreover, CIS surveys are subject to extensive pre-testing and piloting in various countries, industries and firms with regard to interpretability, reliability and validity (Laursen and Salter, 2006). This multinational application of CIS surveys adds extra layers of quality management and assurance.

After complementing the dataset with official statistics for overall business $R \& D$ expenditure at the industry level from OECD ANBERD database, our final data set contains 1,572 observations.

\section{Dependent variables}

We construct two scales representing market-based and legal knowledge protection which will serve as dependent variables. Both scales are constructed by combining various instruments used by firms to protect their knowledge following Laursen and Salter (2005). These instruments include patents, copyrights, trademarks, industrial design, secrecy, lead time and complex design. In the questionnaire firms are asked to state the importance of each instrument in a four point Likert-based scale with 3 meaning "instrument is very important" and 0 "instrument is not relevant at all". In order to group these instruments to the marketbased and legal knowledge protection scales respectively we apply an exploratory principal component analysis. We make use of a varimax rotation with Kaiser Normalization. The KMO-value with 0.76 indicates that the input variables are "meritoriously" suitable for a factor analysis (Kaiser and Rice, 1974: p.11). Two factors with eigenvalues greater than one are yielded which capture more than $60 \%$ of total variance (see Appendix A for details), each of which corresponding to one dimension of knowledge protection. The solution is robust as split-half-test yield similar solutions with two factors and comparable factor structure. The factor structure is meaningful and clear with no issues loading relatively high in both features (see Table 1 for the rotated factor loadings). Our results support theoretical findings of previous studies discussed in chapter 2 concerning the affiliation of knowledge protection instruments to both types of knowledge protection strategies. The pattern of factor loadings and their consistency indicate the high content validity of the yielded solution and can be considered as a consistency check of our data.

Table 1: Factor loadings after varimax rotation

\begin{tabular}{|l|c|c|}
\hline Instruments & Factor 1 & Factor 2 \\
\hline Patent & 0.73 & 0.23 \\
\hline Design pattern & 0.79 & 0.10 \\
\hline Trademark & 0.67 & 0.15 \\
\hline
\end{tabular}




\begin{tabular}{|l|c|c|}
\hline Instruments & Factor 1 & Factor 2 \\
\hline Copyright & 0.52 & 0.16 \\
\hline Secrecy & 0.30 & 0.75 \\
\hline Complex design & -0.08 & 0.80 \\
\hline Lead time & 0.25 & 0.80 \\
\hline
\end{tabular}

The first factor shows strong emphasis on secrecy, complex design and lead time and represents the importance of market-based knowledge protection strategies, whereas the second, has a focus on legal instruments, i.e. patents, design patterns, trademarks and copyrights, and is therefore labeled as legal knowledge protection.

Factor scores of both factors, retained by means of regression analysis, are used as dependent variables for our further analysis.

\section{Independent variables}

The focal point of our analysis is the investigation of knowledge protection strategies of MNCs. A dummy variable which indicates whether the firm is part of a multinational group with headquarters abroad is the most important variable in our model. Managers indicate this status themselves in the questionnaire. The estimation parameter of this dummy variable incorporates the impact of MNC on knowledge protection. The sign and intensity of this estimator indicates how MNC subsidiary managers choose distinctively different marketbased and legal strategies due to the fact that they belong to an MNC.

To define the reference group of purely domestic firms more precisely we add an additional variable indicating whether a firm is part of a group with domestic headquarters ("domestic group"). Purely domestic firms (not part of a group) will therefore serve as the comparison group.

Most importantly, knowledge protection strategies may differ with regard to firms' innovation and knowledge production engagements. We control for major innovation inputs by using $R \& D$ expenditures as a share of sales, the share of employees with college education and whether the firm performs R\&D activities continuously (often associated with having a dedicated R\&D department).

Several studies highlight the importance of subsidiary assignments from headquarters for explaining their behavior (e.g. Birkinshaw and Fry, 1998; Birkinshaw and Hood, 1998; Hakanson and Nobel, 2001). Cantwell and Mudambi (2005) provide an in-depth discussion of subsidiary mandates, relating them back to March (1991) and the distinction between explorative (directed towards new product, capabilities and markets) and exploitative innovation activities (built around and for existing capabilities and customers). We construct two indices for explorative and exploitative innovation strategies based on a question of the effects of a firm's innovation activities. Again, firms rank several items on a four point Likert scale ranging from not relevant to highly important. We add up relevant items and divide them by the maximum. Firms' innovation strategies are considered explorative based on the importance of generating new products and serving new markets. Innovation strategies are considered exploitative if quality improvements, resources and personnel cost reductions are dominant. Moreover, we control for how long a firm has been operating in Germany (company age as years since founding) because potential "liability of newness"-effects may 
also influence subsidiary host country embeddedness and subsequent behavior (e.g. Hakanson and Nobel, 2001).

Previous studies have identified several structural firm features which influence the choice of certain knowledge protection strategies especially with an eye on the propensity to patent. These include resource availability (firm size), type of innovation activity (product/process) and industry (e.g. Arundel and Kabla, 1998; Brouwer and Kleinknecht, 1999; Byma and Leiponen, 2006; Harabi, 1995). Hence, we incorporate these control variables into the model: Firm size (number of employees in logs), whether the firm was active in process innovation as well as five industry dummies (medium high-tech manufacturing, high-tech manufacturing, distributive services, knowledge-intensive services and technological services). Low-tech manufacturing will serve as the comparison group (see Appendix C for industry classification). We also control for a firms' degree of internationalization through the export share of their sales.

\section{Moderator variables}

The host country environment is described along two dimensions: (a) the industry in which the MNC subsidiary operates and (b) its geographical location. In order to represent the degree of technological leadership of industry and geographical environment of host country we construct three R\&D-indices following Salomon and Byungchae (2008).

We use the OECD ANBERD database on business R\&D expenditures to construct the R\&D index. Data covers the year 2002 (the beginning of the survey observation period) so that it can be considered predetermined. The R\&D-industry index is built by comparing the R\&D expenditures (as a share of industry GDP) of the relevant industry in Germany with the average one of all other OECD countries. First, the R\&D expenditure in industry $i$ is scaled by GDP of host country (Germany). Next, the resulting ratio is averaged across all countries in OECD besides Germany. In a last step the mean is subtracted from the equivalent measure for Germany in the matching industry $i$ (see also Salomon and Byungchae, 2008). The result is an industry specific R\&D index comparing industries in Germany with those in the rest of OECD on the basis of R\&D expenditures. Positive values of the index indicate relative technological leadership of host country (Germany) in a particular industry, whereas negative values indicate that the host country is a technological laggard in a given industry.

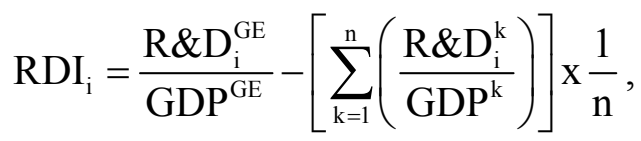

where $R D I_{i}$ represents the $\mathrm{R} \& \mathrm{D}$-index of industry $i, \mathrm{R} \& \mathrm{D}_{\mathrm{i}}^{\mathrm{GE}}$ is the $\mathrm{R} \& \mathrm{D}$ expenditure for industry $i$ in Germany, GDP $P^{G E}$ the GDP of Germany, $R \& D_{i}^{k}$ is the R\&D expenditure for industry $i$ in country $k, G D P_{k}$ is the GDP of country $k$ and $n$ the number of OECD countries excluding Germany.

Similarly we construct two geographical R\&D indices used for indicating relative technological leadership of an MNC subsidiary geographical location in reference to the rest of host country (Germany). We obtain regional data on business R\&D expenditures and GDP 
for 2001 from the German federal statistical office (Destatis) and from the European statistical office (Eurostat). Geographical location is defined broadly in the first index (federal state in Germany) and more narrowly in the second (district where the firm is positioned). Germany comprises 16 federal states which are subdivided into 439 districts (NUTS3). We calculate two separate geographical R\&D indices using both geographical units. Both indices are calculated as follows:

$\mathrm{RDI}_{\mathrm{d}}=\frac{{\mathrm{R} \& D_{\mathrm{d}}}_{\mathrm{GDP}^{\mathrm{d}}}}{\mathrm{GD}_{\mathrm{k}=1}}\left[\sum_{\mathrm{GDP}}^{\mathrm{n}}\left(\frac{\mathrm{R} \& \mathrm{D}^{\mathrm{k}}}{\mathrm{G}}\right)\right] \mathrm{x} \frac{1}{\mathrm{n}}$,

whereas the index $d$ represents the state or district depending on geographical unit used, with $R D I_{d}$ representing the R\&D index of state or district $d, G D P^{d}$ the GDP of respective state of district $d, R^{k}$ the R\&D expenditure in state or district $k, G D P^{k}$ the GDP of state or district $k$. $N$ represents the number of states or districts excluding the actual one (d). Hence, in case of using states as a geographical unit, $n$ can take values from 1 to 15 , whereas when using districts the value range for $n$ goes from 1 to 438. Figure 2 provides a map of the results.

Figure 1: Share of business R\&D expenditures on GDP at state and district level 2001
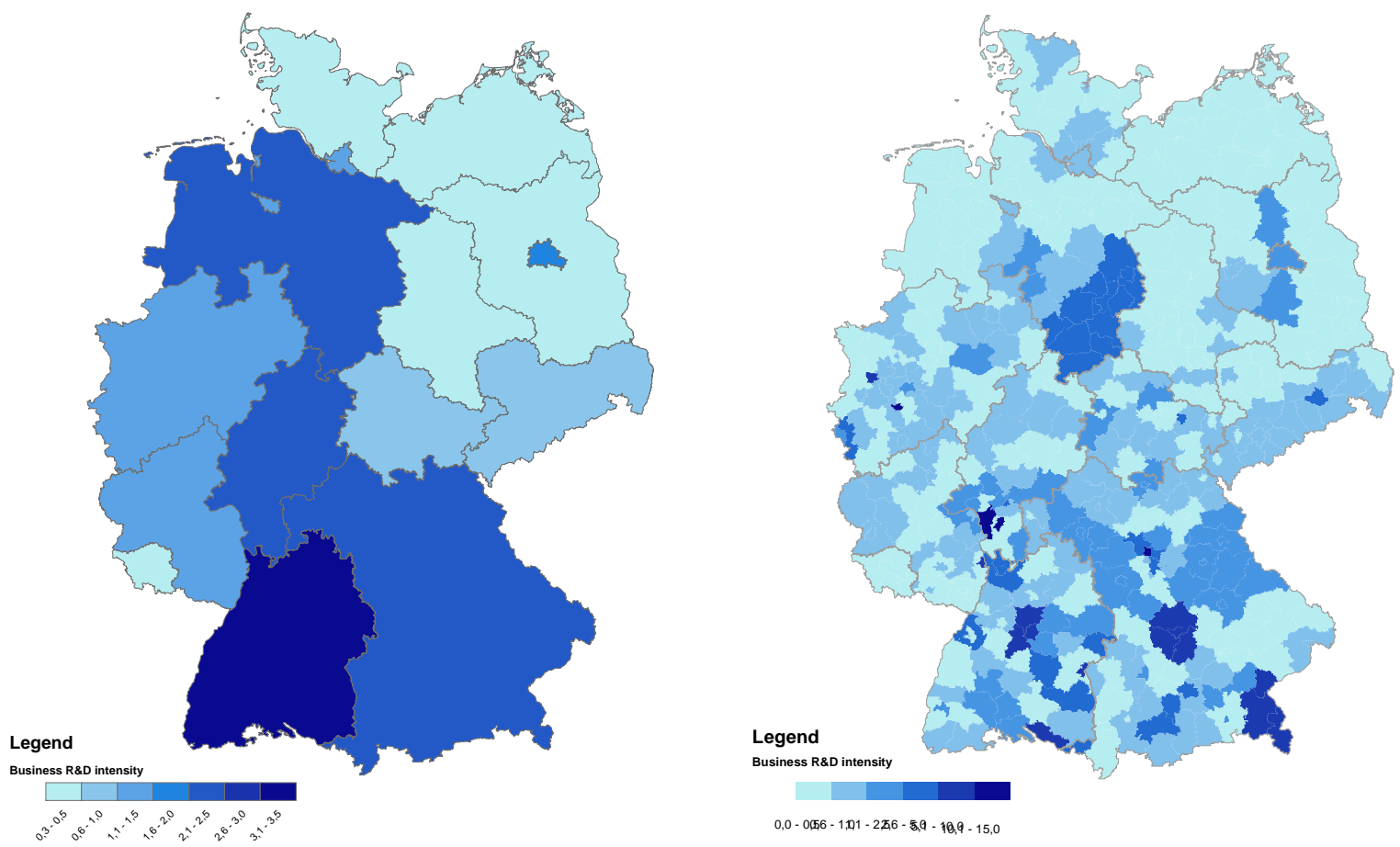

Source: Own calculation and illustration based on OECD, Destatis and Eurostat data.

We test both geographical indices in our model in order to investigate which geographical unit has the highest impact on knowledge protection strategies for MNC companies.

\section{Descriptive Statistics and Correlations}

Table 2 displays descriptive statistics of the knowledge protection instruments for the whole sample as well as separately for foreign MNCs and subsidiaries and domestic firms. Heads of R\&D or innovation management indicate the importance of various instruments for their firms in four-point Likert-based scale. We calculate the means and standard deviations of 
these data. The results reveal clear differences between foreign MNC subsidiaries and domestic firms. Foreign MNC subsidiaries seem to use a wider variety of protection instruments more extensively. For testing the significance of differences between MNC subsidiaries and domestic firms we use the Smith-Sautterthwaite test which is especially appropriate for different sized and small samples (see Appendix D for test details).

The t-values as well as the error probabilities are displayed in Table 2. The statistical results indicate first empirical evidence for our hypotheses: significant differences are identified in the relevance of six out of the eight considered knowledge protection instruments. The significant differences contain however legal as well as market-based instruments so that it cannot be clearly recognized which kind of knowledge protection (market based vs. legal) is more relevant for foreign MNC subsidiaries as compared to domestic firms. The results of the market-based instruments do not give a uniform picture: whereas secrecy becomes significantly more important for foreign MNC subsidiaries, differences concerning complex designs and lead time are not statistically significant.

Table 2: Relevance of knowledge protection instruments for MNC and domestic firms

\begin{tabular}{|c|c|c|c|c|c|c|c|}
\hline \multicolumn{3}{|c|}{$\begin{array}{l}\text { Knowledge Protection } \\
\text { Instrument }\end{array}$} & \multirow{2}{*}{$\begin{array}{r}\begin{array}{l}\text { Sample } \\
\mathrm{N}=1,572\end{array} \\
0.85 \\
1.27 \\
\end{array}$} & \multirow{2}{*}{$\begin{array}{r}\mathrm{MNC} \\
\mathrm{N}=166 \\
1.53 \\
1.41 \\
\end{array}$} & \multirow{2}{*}{$\begin{aligned} \begin{array}{l}\text { DOM. } \\
\mathrm{N}=1,472\end{array} \\
0.77 \\
1.23\end{aligned}$} & $\begin{array}{l}\text { t-Value } \\
\text { (paired } \\
\text { t-Test) }\end{array}$ & \multirow{2}{*}{$\begin{array}{l}\alpha \\
0 \%\end{array}$} \\
\hline \multirow{4}{*}{ 弌 } & Patent & $\begin{array}{l}\text { Mean } \\
\text { Std. Dev. }\end{array}$ & & & & $7.23 *$ & \\
\hline & Design pattern & $\begin{array}{l}\text { Mean } \\
\text { Std. Dev. }\end{array}$ & $\begin{array}{l}0.58 \\
1.08 \\
\end{array}$ & $\begin{array}{l}0.84 \\
1.24 \\
\end{array}$ & $\begin{array}{l}0.54 \\
1.06 \\
\end{array}$ & $3.33 *$ & $0 \%$ \\
\hline & Trademark & $\begin{array}{l}\text { Mean } \\
\text { Std. Dev. }\end{array}$ & $\begin{array}{l}0.60 \\
1.11 \\
\end{array}$ & $\begin{array}{l}0.73 \\
1.19 \\
\end{array}$ & $\begin{array}{l}0.59 \\
1.10\end{array}$ & $1.53 * * *$ & $6 \%$ \\
\hline & Copyright & $\begin{array}{l}\text { Mean } \\
\text { Std. Dev. }\end{array}$ & $\begin{array}{l}0.22 \\
0.74\end{array}$ & $\begin{array}{l}0.31 \\
0.89\end{array}$ & $\begin{array}{l}0.21 \\
0.72\end{array}$ & $1.65 *$ & $5 \%$ \\
\hline \multirow{3}{*}{ 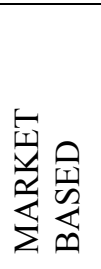 } & Secrecy & $\begin{array}{l}\text { Mean } \\
\text { Std. Dev. }\end{array}$ & $\begin{array}{l}1.20 \\
1.37 \\
\end{array}$ & $\begin{array}{l}1.58 \\
1.41 \\
\end{array}$ & $\begin{array}{l}1.15 \\
1.36 \\
\end{array}$ & $3.72 *$ & $0 \%$ \\
\hline & Complex design & $\begin{array}{l}\text { Mean } \\
\text { Std. Dev. }\end{array}$ & $\begin{array}{l}0.53 \\
1.06 \\
\end{array}$ & $\begin{array}{l}0.46 \\
1.04 \\
\end{array}$ & $\begin{array}{l}0.53 \\
1.07\end{array}$ & -0.87 & $19 \%$ \\
\hline & Lead time & $\begin{array}{l}\text { Mean } \\
\text { Std. Dev. }\end{array}$ & $\begin{array}{l}1.30 \\
1.42 \\
\end{array}$ & $\begin{array}{l}1.41 \\
1.45 \\
\end{array}$ & $\begin{array}{l}1.28 \\
1.42 \\
\end{array}$ & 1.08 & $14 \%$ \\
\hline
\end{tabular}

In a further step we divide the foreign MNC subsidiary group into subsets according to the host country environment and consider descriptive statistics of all groups in order to investigate further differences. Respectively two subsets are yielded for both R\&D indices a) foreign MNC subsidiaries operating in technologically leading host country industries versus technological laggards and b) foreign MNC subsidiaries located at technologically advanced geographical areas versus technologically lagging ones. The respective median values of R\&D indices are used as cutoff values. We use the R\&D-index based on federal states as geographical unit when considering technological advantage of geographical environment.

Again we aim to detect significant differences between the means in the respective groups by using the Smith-Sautterthwaite test. Our expectations are confirmed: significant differences are detected depending on the technological leadership of the host environment of the foreign MNC subsidiary along both dimensions. While using the industry as a dimension 
for technological leadership we discover that foreign MNC subsidiaries choose generally more restrictive knowledge protection strategies when operating in industries where the host country, in our case Germany, is a technological laggard compared to OECD average. In this case protection strategies become more relevant compared to technologically advanced industries This is expressed in the significantly higher relevance of protection instruments. Especially patents and secrecy seem to gain in importance for protecting knowledge when the host country is a technological laggard concerning the operating industry of foreign MNC subsidiaries. Even in this case differences occur in both market-based as well as in the legal group, so that no clear differentiation pattern can be discovered.

Technological advantage of geographical location seems to influence the intensity of knowledge protection for foreign MNC subsidiaries in the opposite direction. When located in technologically advanced areas (federal states) foreign MNC subsidiaries seem to protect knowledge more restrictively. Although this finding seems to be against our expectations, it can be explained considering the higher risk of knowledge spill-outs in highly developed geographical areas due to personnel turnover. Loosing highly qualified employees and thus valuable knowledge to competitors becomes more likely in these regions. Hence, knowledge protection management tempting to prevent or regulate the transfer of knowledge becomes more important.

Table 3: Knowledge protection instruments for MNC in different environments

\begin{tabular}{|c|c|c|c|c|c|c|c|c|c|c|c|}
\hline \multicolumn{3}{|c|}{ Knowledge Protection Instruments } & \multicolumn{5}{|c|}{ Industry } & \multicolumn{4}{|c|}{ Location } \\
\hline & & & $\begin{array}{l}\mathrm{MNC} \\
\mathrm{RDI}>0 \\
\mathrm{~N}=105\end{array}$ & $\begin{array}{l}\mathrm{MNC} \\
\mathrm{RDI}<0 \\
\mathrm{~N}=61\end{array}$ & $\begin{array}{l}\mathrm{t}- \\
\text { Value }\end{array}$ & & $\alpha$ & $\begin{array}{l}\mathrm{MNC} \\
\mathrm{RDI}>0 \\
\mathrm{~N}=79\end{array}$ & $\begin{array}{l}\mathrm{MNC} \\
\mathrm{RDI}<0 \\
\mathrm{~N}=87 \\
\end{array}$ & $\begin{array}{l}\mathrm{t}- \\
\text { Value }\end{array}$ & $\alpha$ \\
\hline \multirow{4}{*}{ 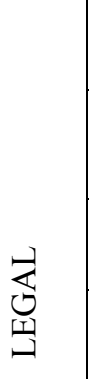 } & Patent & $\begin{array}{l}\text { Mean } \\
\text { Std. Dev. }\end{array}$ & $\begin{array}{l}0.18 \\
1.35\end{array}$ & $\begin{array}{l}1.00 \\
1.37\end{array}$ & -3.72 & $*$ & $0 \%$ & $\begin{array}{l}1.70 \\
1.41\end{array}$ & $\begin{array}{l}1.34 \\
1.40 \\
\end{array}$ & $1.65 * *$ & $5 \%$ \\
\hline & Design pattern & $\begin{array}{l}\text { Mean } \\
\text { Std. Dev. }\end{array}$ & $\begin{array}{l}0.93 \\
1.29 \\
\end{array}$ & $\begin{array}{l}0.69 \\
1.15 \\
\end{array}$ & 1.27 & $\begin{array}{l}* \\
*\end{array}$ & $10 \%$ & $\begin{array}{l}1.18 \\
1.31 \\
\end{array}$ & $\begin{array}{l}0.47 \\
1.05 \\
\end{array}$ & $3.91 *$ & $0 \%$ \\
\hline & Trademark & $\begin{array}{l}\text { Mean } \\
\text { Std. Dev. }\end{array}$ & $\begin{array}{l}0.81 \\
1.26 \\
\end{array}$ & $\begin{array}{l}0.59 \\
1.04 \\
\end{array}$ & 1.21 & & $11 \%$ & $\begin{array}{l}0.89 \\
1.24 \\
\end{array}$ & $\begin{array}{l}0.56 \\
1.11 \\
\end{array}$ & $1.80 * *$ & $4 \%$ \\
\hline & Copyright & $\begin{array}{l}\text { Mean } \\
\text { Std. Dev. }\end{array}$ & $\begin{array}{l}0.36 \\
0.97\end{array}$ & $\begin{array}{l}0.23 \\
0.72 \\
\end{array}$ & 1.00 & & $16 \%$ & $\begin{array}{l}0.51 \\
1.09\end{array}$ & $\begin{array}{l}0.10 \\
0.52 \\
\end{array}$ & $3.10 *$ & $0 \%$ \\
\hline \multirow{3}{*}{ 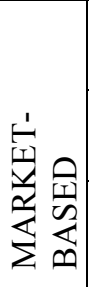 } & Secrecy & $\begin{array}{l}\text { Mean } \\
\text { Std. Dev. }\end{array}$ & $\begin{array}{l}1.83 \\
1.37 \\
\end{array}$ & $\begin{array}{l}1.15 \\
1.38 \\
\end{array}$ & 3.08 & $*$ & $0 \%$ & $\begin{array}{l}1.75 \\
1.39 \\
\end{array}$ & $\begin{array}{l}1.39 \\
1.41 \\
\end{array}$ & $1.63 * *$ & $5 \%$ \\
\hline & Complex design & $\begin{array}{l}\text { Mean } \\
\text { Std. Dev. }\end{array}$ & $\begin{array}{l}0.51 \\
1.11 \\
\end{array}$ & $\begin{array}{l}0.36 \\
0.90 \\
\end{array}$ & 0.97 & & $17 \%$ & $\begin{array}{l}0.52 \\
1.08 \\
\end{array}$ & $\begin{array}{l}0.39 \\
0.99 \\
\end{array}$ & 0.78 & $22 \%$ \\
\hline & Lead time & $\begin{array}{l}\text { Mean } \\
\text { Std. Dev. }\end{array}$ & $\begin{array}{l}1.52 \\
1.45 \\
\end{array}$ & $\begin{array}{l}1.21 \\
1.44 \\
\end{array}$ & 1.34 & $\begin{array}{l}* * \\
*\end{array}$ & $9 \%$ & $\begin{array}{l}1.62 \\
1.44\end{array}$ & $\begin{array}{l}1.18 \\
1.43 \\
\end{array}$ & $1.99 * *$ & $2 \%$ \\
\hline
\end{tabular}

Appendix B provides correlation coefficients and descriptive statistics for all variables in our study. Dependent variables are standardized in order to control for scaling effects. Exceptions are the natural logarithm of the number of employees as well as the R\&D indices for both industry and location. An inspection of the correlation matrix does not reveal any multicollinearity issues, showing a mean inflation factor (VIF) of 1.40. 


\section{$4 \quad$ Results}

Table 4 shows the results of the regression analysis. We estimate four separate empirical models for the legal and market-based knowledge protection scales respectively. Model I can be considered a base model without interaction terms. We find that foreign MNC subsidiary managers choose significantly less restrictive market-based knowledge protection strategies than domestic firms but do not deviate with regards to the restrictiveness of legal knowledge protection. Hence, hypothesis 1 has to be rejected. As suggested in the theoretical section we explore further contingencies on these choices by adding interaction terms. In model II we interact the foreign MNC status with the R\&D index of the host country industry. The latter reflects whether a German industry is leading or lagging in $R \& D$ intensity compared to all other OECD countries. Besides, we add an equivalent interaction effect for the leadership status of the German state a company is located in, compared to all other 15 states. The estimation results reveal an interesting distinction compared to the base model I. With regard to legal knowledge protection strategies we find that the geographical area is the decisive contingency for MNC subsidiary managers. They choose more restrictive legal strategies in technologically leading host country states. The leadership status of the industry, though, has no significant impact. This result provides support for hypotheses $2 \mathrm{a}$ and 4 . However, we find strikingly different results for market-based knowledge protection strategies (Model IIb). MNC subsidiary managers choose less restrictive market-based strategies in technologically leading host country industries while the status of the state (geographical area) has no such effect. Therefore, the finding of the base model on less restrictive market-based knowledge protection strategies is confined to technologically leading host country industries. These results lend support to hypotheses $2 \mathrm{~b}$ and 3 .

We define the relevant geographical environment of an foreign MNC subsidiary more narrowly at the district level (NUTS3) in model III and retain the same results. However, the significance level of the more restrictive legal protection strategies drops indicating that the state-level appears to be more appropriate. Finally, we add another interaction term in model IV accounting for simultaneous industry and geographically leadership status effect. This estimation yields no additional insights and can be considered as a consistency check.

In summary, we find a differentiated picture for foreign MNC subsidiary management choices on the restrictiveness of their knowledge protection strategies. They choose more restrictive legal protection strategies within geographical regions of host country leadership and less restrictive market-based ones within technologically leading industries. We will return to this distinction when discussing these results in the following section. 
Table 4: Regression results

\begin{tabular}{|c|c|c|c|c|c|c|c|c|}
\hline $\begin{array}{l}\text { Model } \\
\text { Variable }\end{array}$ & $\begin{array}{c}\text { Ia } \\
\text { Legal } \\
\text { knowl. prot. } \\
\text { (scale) }\end{array}$ & $\begin{array}{c}\text { Ib } \\
\text { Market-based } \\
\text { knowl. prot. } \\
\text { (scale) }\end{array}$ & $\begin{array}{c}\text { IIa } \\
\text { Legal knowl. } \\
\text { prot. (scale) }\end{array}$ & $\begin{array}{c}\text { IIb } \\
\text { Market- } \\
\text { based knowl. } \\
\text { prot. (scale) }\end{array}$ & $\begin{array}{c}\text { IIIa } \\
\text { Legal } \\
\text { knowl. prot. } \\
\text { (scale) }\end{array}$ & $\begin{array}{c}\text { IIIb } \\
\text { Market-based } \\
\text { knowl. prot. } \\
\text { (scale) }\end{array}$ & $\begin{array}{c}\text { IVa } \\
\text { Legal } \\
\text { knowl. prot. } \\
\text { (scale) }\end{array}$ & $\begin{array}{c}\text { IVb } \\
\text { Market-based } \\
\text { knowl. prot. } \\
\text { (scale) }\end{array}$ \\
\hline Foreign MNC (d) & $\begin{array}{c}0.05 \\
(0.09) \\
\end{array}$ & $\begin{array}{c}-0.18^{* *} \\
(0.08) \\
\end{array}$ & $\begin{array}{l}-0.08 \\
(0.10) \\
\end{array}$ & $\begin{array}{l}-0.10 \\
(0.09) \\
\end{array}$ & $\begin{array}{l}-0.02 \\
(0.09) \\
\end{array}$ & $\begin{array}{l}-0.11 \\
(0.09) \\
\end{array}$ & $\begin{array}{l}-0.01 \\
(0.09) \\
\end{array}$ & $\begin{array}{l}-0.12 \\
(0.09)\end{array}$ \\
\hline Domestic MNC (d) & $\begin{array}{c}0.09 \\
(0.09)\end{array}$ & $\begin{array}{c}0.02 \\
(0.08)\end{array}$ & $\begin{array}{c}0.09 \\
(0.09)\end{array}$ & $\begin{array}{c}0.01 \\
(0.08)\end{array}$ & $\begin{array}{c}0.10 \\
(0.09)\end{array}$ & $\begin{array}{c}0.02 \\
(0.08)\end{array}$ & $\begin{array}{c}0.10 \\
(0.09)\end{array}$ & $\begin{array}{c}0.02 \\
(0.08)\end{array}$ \\
\hline Interact: RDI * foreign & & & $\begin{array}{c}0.04 \\
(0.08) \\
\end{array}$ & $\begin{array}{c}-0.20 * * * \\
(0.06) \\
\end{array}$ & $\begin{array}{c}0.04 \\
(0.09) \\
\end{array}$ & $\begin{array}{c}-0.20 * * * \\
(0.06) \\
\end{array}$ & $\begin{array}{l}-0.01 \\
(0.08) \\
\end{array}$ & $\begin{array}{c}-0.16^{* *} \\
(0.08) \\
\end{array}$ \\
\hline Interact: RDI * domestic & & & $\begin{array}{l}-0.01 \\
(0.05)\end{array}$ & $\begin{array}{c}0.03 \\
(0.05)\end{array}$ & $\begin{array}{l}-0.02 \\
(0.05)\end{array}$ & $\begin{array}{c}0.02 \\
(0.05)\end{array}$ & $\begin{array}{l}-0.02 \\
(0.05)\end{array}$ & $\begin{array}{c}0.02 \\
(0.05)\end{array}$ \\
\hline Inteact: StateIndex * foreign & & & $\begin{array}{c}0.33^{* * *} \\
(0.09) \\
\end{array}$ & $\begin{array}{c}0.04 \\
(0.07) \\
\end{array}$ & & & & \\
\hline Inteact: StateIndex $*$ domestic & & & $\begin{array}{l}0.06^{* * *} \\
(0.02)\end{array}$ & $\begin{array}{l}0.06^{* *} \\
(0.03)\end{array}$ & & & & \\
\hline Interact: DistrictIndex * foreign & & & & & $\begin{array}{l}0.07 * \\
(0.04)\end{array}$ & $\begin{array}{c}0.02 \\
(0.03)\end{array}$ & $\begin{array}{c}0.06 \\
(0.04)\end{array}$ & $\begin{array}{c}0.03 \\
(0.03)\end{array}$ \\
\hline Interact: DistrictIndex * domestic & & & & & $\begin{array}{l}-0.01 \\
(0.01) \\
\end{array}$ & $\begin{array}{c}0.01 \\
(0.01) \\
\end{array}$ & $\begin{array}{l}-0.00 \\
(0.01) \\
\end{array}$ & $\begin{array}{c}0.01 \\
(0.01) \\
\end{array}$ \\
\hline Interact: RDI * DistrictIndex * foreign & & & & & & & $\begin{array}{c}0.03 \\
(0.03)\end{array}$ & $\begin{array}{c}-0.02 \\
(0.02)\end{array}$ \\
\hline Interact: RDI * DistrictIndex $*$ domestic & & & & & & & $\begin{array}{l}-0.04 \\
(0.03)\end{array}$ & $\begin{array}{c}0.00 \\
(0.03) \\
\end{array}$ \\
\hline Company age (years) & $\begin{array}{c}0.00 \\
(0.00) \\
\end{array}$ & $\begin{array}{l}-0.00 \\
(0.00) \\
\end{array}$ & $\begin{array}{c}0.00 \\
(0.00) \\
\end{array}$ & $\begin{array}{l}-0.00^{*} \\
(0.00)\end{array}$ & $\begin{array}{c}0.00 \\
(0.00) \\
\end{array}$ & $\begin{array}{l}-0.00 \\
(0.00) \\
\end{array}$ & $\begin{array}{c}0.00 \\
(0.00)\end{array}$ & $\begin{array}{l}-0.00 \\
(0.00) \\
\end{array}$ \\
\hline Share R\&D exp. of sales (ratio) & $\begin{array}{c}1.05^{* * *} \\
(0.35)\end{array}$ & $\begin{array}{l}0.64^{*} \\
(0.37) \\
\end{array}$ & $\begin{array}{c}1.05^{* * *} \\
(0.35)\end{array}$ & $\begin{array}{l}0.69^{*} \\
(0.37)\end{array}$ & $\begin{array}{c}1.05^{* * *} \\
(0.36)\end{array}$ & $\begin{array}{l}0.66^{*} \\
(0.37) \\
\end{array}$ & $\begin{array}{c}1.04 * * * \\
(0.36)\end{array}$ & $\begin{array}{l}0.67^{*} \\
(0.37) \\
\end{array}$ \\
\hline Contin. R\&D activities (d) & $\begin{array}{c}0.23 * * * \\
(0.06)\end{array}$ & $\begin{array}{c}0.42 * * * \\
(0.06)\end{array}$ & $\begin{array}{c}0.24 * * * \\
(0.06)\end{array}$ & $\begin{array}{c}0.42 * * * \\
(0.06)\end{array}$ & $\begin{array}{c}0.24 * * * \\
(0.06)\end{array}$ & $\begin{array}{c}0.42 * * * \\
(0.06)\end{array}$ & $\begin{array}{c}0.24 * * * \\
(0.06)\end{array}$ & $\begin{array}{c}0.42 * * * \\
(0.06)\end{array}$ \\
\hline Share empl. w/ college educ. (ratio) & $\begin{array}{c}0.07 \\
(0.12)\end{array}$ & $\begin{array}{c}0.44 * * * \\
(0.14)\end{array}$ & $\begin{array}{c}0.08 \\
(0.12)\end{array}$ & $\begin{array}{c}0.47 * * * \\
(0.14)\end{array}$ & $\begin{array}{c}0.07 \\
(0.12)\end{array}$ & $\begin{array}{c}0.44 * * * \\
(0.14)\end{array}$ & $\begin{array}{c}0.07 \\
(0.12)\end{array}$ & $\begin{array}{c}0.45^{* * *} \\
(0.14)\end{array}$ \\
\hline Explorative innovation strategy (index) & $\begin{array}{c}0.28 * * * \\
(0.08) \\
\end{array}$ & $\begin{array}{c}0.45^{* * *} \\
(0.09) \\
\end{array}$ & $\begin{array}{c}0.27 * * * \\
(0.08) \\
\end{array}$ & $\begin{array}{c}0.44 * * * \\
(0.09) \\
\end{array}$ & $\begin{array}{c}0.27 * * * \\
(0.08) \\
\end{array}$ & $\begin{array}{c}0.44 * * * \\
(0.09) \\
\end{array}$ & $\begin{array}{c}0.27 * * * \\
(0.08) \\
\end{array}$ & $\begin{array}{c}0.44 * * * \\
(0.09) \\
\end{array}$ \\
\hline Exploitative innovation strategy (index) & $\begin{array}{c}0.08 \\
(0.10) \\
\end{array}$ & $\begin{array}{c}0.28 * * * \\
(0.10)\end{array}$ & $\begin{array}{c}0.06 \\
(0.10) \\
\end{array}$ & $\begin{array}{c}0.29 * * * \\
(0.11)\end{array}$ & $\begin{array}{c}0.07 \\
(0.10) \\
\end{array}$ & $\begin{array}{c}0.29 * * * \\
(0.10)\end{array}$ & $\begin{array}{c}0.06 \\
(0.10) \\
\end{array}$ & $\begin{array}{c}0.29 * * * \\
(0.10)\end{array}$ \\
\hline
\end{tabular}




\begin{tabular}{|c|c|c|c|c|c|c|c|c|}
\hline $\begin{array}{l}\text { Model } \\
\text { Variable }\end{array}$ & $\begin{array}{c}\text { Ia } \\
\text { Legal } \\
\text { knowl. prot. } \\
\text { (scale) }\end{array}$ & $\begin{array}{c}\mathrm{Ib} \\
\text { Market-based } \\
\text { knowl. prot. } \\
\text { (scale) }\end{array}$ & $\begin{array}{c}\text { IIa } \\
\text { Legal knowl. } \\
\text { prot. (scale) }\end{array}$ & $\begin{array}{c}\text { IIb } \\
\text { Market- } \\
\text { based knowl. } \\
\text { prot. (scale) }\end{array}$ & $\begin{array}{c}\text { IIIa } \\
\text { Legal } \\
\text { knowl. prot. } \\
\text { (scale) }\end{array}$ & $\begin{array}{c}\text { IIIb } \\
\text { Market-based } \\
\text { knowl. prot. } \\
\text { (scale) }\end{array}$ & $\begin{array}{c}\text { IVa } \\
\text { Legal } \\
\text { knowl. prot. } \\
\text { (scale) }\end{array}$ & $\begin{array}{c}\text { IVb } \\
\text { Market-based } \\
\text { knowl. prot. } \\
\text { (scale) }\end{array}$ \\
\hline Share exports of sales (ratio) & $\begin{array}{c}0.51 * * * \\
(0.12)\end{array}$ & $\begin{array}{l}0.28^{* *} \\
(0.11)\end{array}$ & $\begin{array}{c}0.50^{* * *} \\
(0.12) \\
\end{array}$ & $\begin{array}{l}0.24 * * \\
(0.11) \\
\end{array}$ & $\begin{array}{c}0.51 * * * \\
(0.12) \\
\end{array}$ & $\begin{array}{l}0.26^{* *} \\
(0.11)\end{array}$ & $\begin{array}{c}0.51 * * * \\
(0.12) \\
\end{array}$ & $\begin{array}{l}0.26^{* *} \\
(0.11) \\
\end{array}$ \\
\hline No of employees $(\log )$ & $\begin{array}{c}0.16^{* * * *} \\
(0.02)\end{array}$ & $\begin{array}{l}0.03 * \\
(0.02) \\
\end{array}$ & $\begin{array}{c}0.16^{* * * *} \\
(0.02)\end{array}$ & $\begin{array}{l}0.03 * \\
(0.02) \\
\end{array}$ & $\begin{array}{c}0.16^{* * * *} \\
(0.02)\end{array}$ & $\begin{array}{l}0.03 * \\
(0.02)\end{array}$ & $\begin{array}{c}0.16^{* * * *} \\
(0.02)\end{array}$ & $\begin{array}{l}0.03 * \\
(0.02) \\
\end{array}$ \\
\hline Process innovation $(\mathrm{d})$ & $\begin{array}{c}-0.13 * * * \\
(0.05)\end{array}$ & $\begin{array}{l}0.12 * * \\
(0.05)\end{array}$ & $\begin{array}{c}-0.13 * * * \\
(0.05)\end{array}$ & $\begin{array}{l}0.12 * * \\
(0.05)\end{array}$ & $\begin{array}{c}-0.13^{* *} \\
(0.05)\end{array}$ & $\begin{array}{l}0.12 * * \\
(0.05)\end{array}$ & $\begin{array}{c}-0.13^{* *} \\
(0.05)\end{array}$ & $\begin{array}{l}0.11 * * \\
(0.05)\end{array}$ \\
\hline Medium high-tech manuf. (d) & $\begin{array}{c}0.09 \\
(0.08)\end{array}$ & $\begin{array}{c}0.09 \\
(0.08)\end{array}$ & $\begin{array}{c}0.10 \\
(0.08)\end{array}$ & $\begin{array}{c}0.09 \\
(0.08)\end{array}$ & $\begin{array}{c}0.10 \\
(0.08)\end{array}$ & $\begin{array}{c}0.09 \\
(0.08)\end{array}$ & $\begin{array}{c}0.11 \\
(0.08)\end{array}$ & $\begin{array}{c}0.09 \\
(0.08)\end{array}$ \\
\hline High-tech manuf. (d) & $\begin{array}{c}0.02 \\
(0.09)\end{array}$ & $\begin{array}{c}0.34 * * * \\
(0.09)\end{array}$ & $\begin{array}{c}0.01 \\
(0.09)\end{array}$ & $\begin{array}{c}0.34 * * * \\
(0.09)\end{array}$ & $\begin{array}{c}0.02 \\
(0.09)\end{array}$ & $\begin{array}{c}0.34 * * * \\
(0.09)\end{array}$ & $\begin{array}{c}0.03 \\
(0.09)\end{array}$ & $\begin{array}{c}0.33 * * * \\
(0.09)\end{array}$ \\
\hline Distributive services (d) & $\begin{array}{c}-0.32 * * * \\
(0.06) \\
\end{array}$ & $\begin{array}{c}-0.17 * * \\
(0.07) \\
\end{array}$ & $\begin{array}{c}-0.30 * * * \\
(0.06) \\
\end{array}$ & $\begin{array}{c}-0.16^{* *} \\
(0.07) \\
\end{array}$ & $\begin{array}{c}-0.31 * * * \\
(0.06)\end{array}$ & $\begin{array}{c}-0.17 * * \\
(0.07) \\
\end{array}$ & $\begin{array}{c}-0.31 * * * \\
(0.06) \\
\end{array}$ & $\begin{array}{c}-0.17 * * \\
(0.07) \\
\end{array}$ \\
\hline Knowledge-intens. services (d) & $\begin{array}{c}-0.27 * * * \\
(0.09)\end{array}$ & $\begin{array}{l}-0.03 \\
(0.09)\end{array}$ & $\begin{array}{c}-0.28 * * * \\
(0.08)\end{array}$ & $\begin{array}{l}-0.02 \\
(0.09)\end{array}$ & $\begin{array}{c}-0.28 * * * \\
(0.08)\end{array}$ & $\begin{array}{l}-0.02 \\
(0.09)\end{array}$ & $\begin{array}{c}-0.28 * * * \\
(0.09)\end{array}$ & $\begin{array}{l}-0.02 \\
(0.09)\end{array}$ \\
\hline Technological services $(\mathrm{d})$ & $\begin{array}{c}-0.18^{* *} \\
(0.08) \\
\end{array}$ & $\begin{array}{c}0.01 \\
(0.10)\end{array}$ & $\begin{array}{c}-0.19^{* *} \\
(0.08)\end{array}$ & $\begin{array}{c}0.03 \\
(0.10)\end{array}$ & $\begin{array}{c}-0.20 * * \\
(0.08) \\
\end{array}$ & $\begin{array}{c}0.02 \\
(0.10)\end{array}$ & $\begin{array}{c}-0.20 * * * \\
(0.08)\end{array}$ & $\begin{array}{c}0.02 \\
(0.10) \\
\end{array}$ \\
\hline RDI (index) & $\begin{array}{c}0.00 \\
(0.04) \\
\end{array}$ & $\begin{array}{c}-0.02 \\
(0.04) \\
\end{array}$ & & & & & & \\
\hline District business R\&D index (NUTS3) & $\begin{array}{c}0.01 \\
(0.01)\end{array}$ & $\begin{array}{c}0.01 \\
(0.01)\end{array}$ & & & & & & \\
\hline Constant & $\begin{array}{c}-1.07 * * * \\
(0.10)\end{array}$ & $\begin{array}{c}-0.99 * * * \\
(0.11) \\
\end{array}$ & $\begin{array}{c}-1.05 * * * \\
(0.10)\end{array}$ & $\begin{array}{c}-1.02 * * * \\
(0.11)\end{array}$ & $\begin{array}{c}-1.05 * * * \\
(0.10)\end{array}$ & $\begin{array}{c}-1.00 * * * \\
(0.11)\end{array}$ & $\begin{array}{c}-1.05 * * * \\
(0.10)\end{array}$ & $\begin{array}{c}-1.00 * * * \\
(0.11)\end{array}$ \\
\hline $\mathrm{R} 2$ & 0.25 & 0.20 & 0.26 & 0.21 & 0.25 & 0.21 & 0.25 & 0.21 \\
\hline $\mathrm{N}$ & 1572 & 1572 & 1572 & 1572 & 1572 & 1572 & 1572 & 1572 \\
\hline F-value & 28.25 & 26.86 & 26.51 & 25.20 & 25.69 & 24.32 & 23.44 & 22.29 \\
\hline P-value & 0.00 & 0.00 & 0.00 & 0.00 & 0.00 & 0.00 & 0.00 & 0.00 \\
\hline
\end{tabular}

$* * *, * *, *$ indicate significance of $1 \%, 5 \%$ or $10 \%$; robust standard errors. 
We develop no a priori hypotheses for the control variables. However, major results should be highlighted briefly. Our findings indicate that all knowledge production activities (R\&D) lead to more restrictive knowledge protection strategies (both legal and market-based). The share of college educated employees, though, has only a positive effect on market-based protection methods. This need for protecting valuable knowledge is also reflected in the more exploitative innovation strategies (directed at new products and new markets). Exploitative innovation strategies and process innovation, though, are more likely protected through market-based protection methods. Other studies have found similar results and concluded that the embeddedness of process innovation within a larger production system facilitates marketbased protection methods (Byma and Leiponen, 2006; Harabi, 1995). Managers choose also more restrictive protection strategies (both legal and market-based) with increasing firm size and internationalization which may reflect the availability of resources to do so. Finally, we support existing literature on the industry specificity of knowledge protection (e.g. Arundel and Kabla, 1998; Brouwer and Kleinknecht, 1999). Legal protection strategies are generally less frequently used in service industries. Market-based knowledge protection is more important in high-tech manufacturing and less important in distributive services.

\section{Discussion}

We conduct this study to extend existing research emphasizing the important role of active knowledge protection strategies of MNC subsidiaries beyond location choices (Alcacer and Chung, 2007; Shaver and Flyer, 2000). We hypothesize that MNC subsidiary managers have strong incentives to protect the valuable MNC knowledge as long as it does not negatively interfere with opportunities for sourcing knowledge from the host country environment. We describe this environment along two major dimensions: the technological leadership status of the host country industry and the host country geographical area respectively.

Our empirical investigation among more than 1,500 firms in Germany reveals that both dimensions provide important contingencies to MNC subsidiary managers. However, they differ with regard to the type of knowledge protection. Legal forms of knowledge protection (e.g. patenting) are used more restrictively if the host country geographical environment is technologically leading. We suspect that this is due to the fact that the dangers for knowledge outflows through personnel turnover are especially pressing in these areas as skilled employees would have multiple opportunities to find adequate, new jobs without major distractions to their personal life. These particular spillovers through personnel mobility would render knowledge protection through market-based methods such as secrecy meaningless (see for example Arrow, 1962).

The choice of market-based knowledge protection strategies by MNC subsidiary managers is substantially different. They choose less restrictive ones in technologically leading host country industries. We conclude that demonstrated reciprocity in knowledge exchanges is especially rewarding with technologically leading host country counterparts. Overly restrictive market-based protection strategies, such as secrecy, may severely damage these relationships as they are designed to provide no signals to potential counterparts. In other 
words, host country counterparts would find it especially difficult to judge the potential for knowledge exchanges if the MNC keeps all its knowledge secrete. This mechanism is different from legal protection strategies which imply a formal application process which includes the mandatory disclosure of knowledge in exchange for legal protection (Gallini and Scotchmer, 2002). This provides firms with tangible signals of their research activities for potential partners (Harabi, 1995).

Management recommendations can be derived based on our results. From a management perspective, MNCs need to develop knowledge protection strategies that go beyond patenting. Previous studies have mostly focused on MNC subsidiary patenting activity and location choices (e.g. Alcacer and Chung, 2007; Shaver and Flyer, 2000). However, this may only represent a subset of potential strategic choices for MNC subsidiary management. It may for example not be a feasible option when the subsidiary has been acquired and opportunities for relocating R\&D activities are limited. We find that both legal and market-based knowledge protection strategies should be considered. Both have to reflect host country contingencies along two major dimensions: industry and geography. MNC subsidiaries require formal knowledge protection capabilities such as the specialized patent law competencies when they engage in geographically leading host country regions. Conversely, the budgets for developing and maintaining these capabilities can be limited in host country states or districts with lagging status. Most interestingly, we find that technological opportunities for sourcing knowledge from host country competitors in the same industry require reciprocity with regards to market-based protection strategies (such as secrecy). MNC subsidiary management should be prepared to actively engage in host country knowledge sharing once opportunities arise. In lagging host country industry environments, though, they should increase the restrictiveness these protection mechanisms.

\section{Limitations and further research}

First, we benefit from a comprehensive database. However, our empirical study is limited to the German context. Internationally comparative studies may provide additional insights. Further avenues for further research are possible changes or discontinuities in the host country environment. Such discontinuities, e.g. changes in technology or in the competitive landscape, may influence a firm's choice on knowledge protection strategies. Furthermore, heterogeneity in firm profiles or their capabilities of anticipating changes in host country contingencies could be taken into account in future work.

\section{References}

Adams, J.D. and A.B. Jaffe (1996), Bounding the Effects of R and D: An Investigation Using Matched Establishment-Firm Data, RAND Journal of Economics 27 (4), 700-721.

Aitken, B.J. and A.E. Harrison (1999), Do Domestic Firms Benefit from Direct Foreign Investment?, American Economic Review 89 (3), 605-618.

Alcacer, J. and W. Chung (2007), Location Strategies and Knowledge Spillovers, Management Science 53 (5), 760-776. 
Almeida, P. (1996), Knowledge Sourcing by Foreign Multinationals: Patent Citation Analysis in the U.S. Semiconductor Industry, Strategic Management Journal 17, 155-165.

Almeida, P. and B. Kogut (1999), Localization of Knowledge and the Mobility of Engineers in Regional Networks, Management Science 45 (7), 905-917.

Almeida, P. and A. Phene (2004), Subsidiaries and Knowledge Creation: The Influence of the Mnc and Host Country on Innovation, Strategic Management Journal 25 (8/9), 847864.

Arrow, K.J. (1962), Economic Welfare and the Allocation of Resources for Invention, in: Nelson, R. (ed.) The Rate and Direction of Inventive Activity, Princeton, 609-625.

Arundel, A. and I. Kabla (1998), What Percentage of Innovations Are Patented? Empirical Estimates for European Firms, Research Policy 27, 127-141.

Audretsch, D.B. and M.P. Feldman (1996), R\&D Spillovers and the Geography of Innovation and Production, American Economic Review 86 (3), 630-640.

Branstetter, L.G., R. Fisman and C.F. Foley (2006), Do Stronger Intellectual Property Rights Increase International Technology Transfer? Empirical Evidence from U. S. FirmLevel Panel Data, Quarterly Journal of Economics 121 (1), 321-349.

Brouwer, E. and A. Kleinknecht (1999), Innovative Output, and a Firm's Propensity to Patent. An Exploration of Cis Micro Data, Research Policy 28 (6), 615-624.

Buckley, P.J. and M. Casson (1981), The Optimal Timing of a Foreign Direct Investment, Economic Journal 91 (361), 75-87.

Byma, J. and A. Leiponen (2006), Can'T Block, Must Run: Small Firms and Appropriality, Discussion Papers from The Research Institute of the Finnish Economy No. 1055, Helsinki.

Cassiman, B. and R. Veugelers (2002), R\&D Cooperation and Spillovers: Some Empirical Evidence from Belgium, American Economic Review 44 (3), 1169.

Cohen, W.M., A. Goto, A. Nagata, R.R. Nelson and J.P. Walsh (2002), R\&D Spillovers, Patents and Incentives to Innovate in Japan and the United States., Research Policy 313 (8-9), 1349-1367.

Cohen, W.M., R.R. Nelson and J.P. Walsh (2000), Protecting Their Intellectual Assets: Appropriability Conditions and Why U.S. Manufacturing Firms Patent (or Not), NBER Working Paper No. 7552, Boston.

Encaoua, D., D. Guellec and C. Martinez (2006), Patent Systems for Encouraging Innovation: Lessons from Economic Analysis, Research Policy 35 (9), 1423-1440.

Feinberg, S.E. and A.K. Gupta (2004), Knowledge Spillovers and the Assignment of R\&D Responsibilities to Foreign Subsidiaries, Strategic Management Journal 25 (8/9), 823845. 
Frost, T.S. (2001), The Geographic Sources of Foreign Subsidiaries' Innovations, Strategic Management Journal 22 (2), 101-123.

Furman, J.L. and R. Hayes (2004), Catching up or Standing Still? National Innovative Productivity among 'Follower' Countries, 1978-1999, Research Policy 33 (9), 13291354.

Gallini, N. and S. Scotchmer (2002), Intellectual Property: When Is It the Best Incentive System?, NBER Innovation Policy \& the Economy 2 (1), 51-77.

Gallini, N.T. (2002), The Economics of Patents: Lessons from Recent U.S. Patent Reform., Journal of Economic Perspectives 16 (2), 131-155.

Goshal, S. and C. Bartlett (1990), The Multinational Corporation as an Interorganizational Network, Academy of Management Review 15, 603-625.

Grant, R.M. (1996), Toward a Knowledge-Based Theory of the Firm, Strategic Management Journal 17, 109-122.

Gunnthorsdottir, A., K. McCabe and V. Smith (2002), Using the Machiavellianism Instrument to Predict Trustworthiness in a Bargaining Game, Journal of Economic Psychology 23 (1), 49-66.

Hakanson, L. and R. Nobel (2001), Organizational Characteristics and Reverse Technology Transfer, Management International Review (MIR) 41 (4), 395-420.

Harabi, N. (1995), Appropriability of Technological Innovations - an Empirical Analysis., Research Policy 24, 981-992.

Haskel, J.E., S.C. Pereira and M.J. Slaughter (2007), Does Inward Foreign Direct Investment Boost the Productivity of Domestic Firms?, Review of Economics \& Statistics 89 (3), 482-496.

Ito, B. and R. Wakasugi (2007), What Factors Determine the Mode of Overseas R\&D by Multinationals? Empirical Evidence, Research Policy 36 (8), 1275-1287.

Jaffe, A.B. and M. Trajtenberg (1999), International Knowledge Flows: Evidence from Patent Citations, Economics of Innovation \& New Technology 8 (1/2), 105-137.

Jaffe, A.B., M. Trajtenberg and R. Henderson (1993), Geographic Localization of Knowledge Spillovers as Evidenced by Patent Citations, The Quarterly Journal of Economics 108 (3), 577-599.

Kaiser, H.F. and J. Rice (1974), Little Jiffy, Mark Iv, Educational and Psychological Measurement 34, 111-117.

Keller, W. (2002), Geographical Localization of International Technology Diffusion, American Economic Review 92 (1), 120-140. 
Keller, W. (2004), International Technology Diffusion, Journal of Economic Literature XLII (September 2004), 752-782.

Kogut, B. and U. Zander (1993), Knowledge of the Firm and the Evolutionary Theory of the Multinational Corporation, Journal of International Business Studies 24 (4), 625-645.

Lane, P.J. and M. Lubatkin (1998), Relative Absorptive Capacity and Interorganizational Learning, Strategic Management Journal 19, 461-477.

Laursen, K. and A. Salter (2005), My Precious - the Role of Appropriability Strategies in Shaping Innovative Performance, DRUID Working Paper No. 05-02, Copenhagen.

Laursen, K. and A. Salter (2006), Open for Innovation: The Role of Openness in Explaining Innovation Performance among U.K. Manufacturing Firms, Strategic Management Journal 27 (2), 131-150.

Lieberman, M.B. and D.B. Montgomery (1988), First-Mover Advantages, Strategic Management Journal 9, 41-58.

Mahmood, I.P. and J. Singh (2003), Technological Dynamism in Asia, Research Policy 32 (6), 1031-1054.

Mansfield, E. (1986), Patents and Innovation: An Empirical Study, Management Science 32 (2), 173-181.

Mansfield, E., M. Schwartz and S. Wagner (1981), Imitation Costs and Patents: An Empirical Study, The Economic Journal 91, 907-918.

Nadiri, I.M. (1993), Innovations and Technological Spillovers, NBER Working Paper No. 4423, Cambridge, MA.

OECD (2007), Main Science and Technology Indicators 2007-1, Paris.

Peri, G. (2005), Determinants of Knowledge Flows and Their Effect on Innovation, Review of Economics and Statistics 87 (2), 308-322.

Porter Liebeskind, J. (1997), Keeping Organizational Secrets: Protective Institutional Mechanisms and Their Costs, Industrial \& Corporate Change 6 (3), 623-663.

Porter, M.E. and S. Stern (2000), Measuring The "Ideas" Production Function: Evidence from International Patent Output, NBER Working Paper Series 7891.

Rivette, K.G. and D. Kline (2000), Discovering New Value in Intellectual Property, Harvard Business Review 78 (1), 54-66.

Romer, P.M. (1990), Endogenous Technological Change, Journal of Political Economy 98 (5), 71-102.

Rousseau, D.M., S.B. Sitkin, R.S. Burt and C. Camerer (1998), Not So Different after All: A Cross-Discipline View of Trust, Academy of Management Review 23 (3), 393-404. 
Salomon, R. and J. Byungchae (2008), Does Knowledge Spill to Leaders or Laggards? Exploring Industry Heterogeneity in Learning by Exporting, Journal of International Business Studies 39 (1), 132-150.

Saviotti, P.P. (1998), On the Dynamics of Appropriability, of Tacit and of Codified, Research Policy 26 (7/8), 843-856.

Shaver, J.M. and F. Flyer (2000), Agglomeration Economies, Firm Heterogeneity, and Foreign Direct Investment in the United States, Strategic Management Journal 21 (12), 1175-1193.

Szulanski, G. (1996), Exploring Internal Stickiness: Impediments to the Transfer of Best Practice within the Firm, Strategic Management Journal 17 (Special issue), 27-43.

Teece, D.J. (1998), Capturing Value from Knowledge Assets: The New Economy, Markets for Know-How, and Intagible Assets, California Management Review 40 (3), 55-79.

Todorova, G. and B. Durisin (2007), Absorptive Capacity: Valuing a Reconceptualization, Academy of Management Review 32 (3), 774-786.

Zhao, M. (2006), Conducting R\&D in Countries with Weak Intellectual Property Rights Protection, Management Science 52 (8), 1185-1199.

\section{Appendix A: $\quad$ Results of principal component factor analysis}

\begin{tabular}{|l|l|l|l|l|}
\hline Factor & Eigenvalue & Difference & Proportion & Cumulative \\
\hline Factor1 & 2.79 & 1.58 & 0.40 & 0.40 \\
\hline Factor2 & 1.20 & 0.33 & 0.17 & 0.57 \\
\hline Factor3 & 0.87 & 0.19 & 0.12 & 0.69 \\
\hline Factor4 & 0.68 & 0.09 & 0.10 & 0.79 \\
\hline Factor5 & 0.60 & 0.13 & 0.09 & 0.88 \\
\hline Factor6 & 0.47 & 0.08 & 0.07 & 0.94 \\
\hline Factor7 & 0.39 & - & 0.06 & 1.00 \\
\hline $\begin{array}{l}\text { Cronbach alpha scale reliability coefficient: } 0.75 \\
\text { LR test independent vs. saturated chi2(21) }=2389.60, \text { Prob }>\text { chi2 }=0.0\end{array}$ \\
\hline
\end{tabular}




\section{Appendix B: Correlations and descriptive statistics}

\begin{tabular}{|c|c|c|c|c|c|c|c|c|c|c|c|c|c|c|c|c|c|}
\hline Variable & 1 & 2 & 3 & 4 & 5 & 6 & 7 & 8 & 9 & 10 & 11 & 12 & 13 & 14 & 15 & 16 & 17 \\
\hline 1. Foreign MNC (d) & 1.00 & & & & & & & & & & & & & & & & \\
\hline 2. Domestic MNC (d) & -0.13 & 1.00 & & & & & & & & & & & & & & & \\
\hline 3. Share R\&D exp. of sales (ratio) & -0.03 & -0.02 & 1.00 & & & & & & & & & & & & & & \\
\hline 4. Contin. R\&D activities (d) & 0.14 & 0.19 & 0.32 & 1.00 & & & & & & & & & & & & & \\
\hline 5. Share empl. w/ college educ. (ratio) & -0.02 & 0.01 & 0.39 & 0.18 & 1.00 & & & & & & & & & & & & \\
\hline 6. Explorative innovation strategy (index) & 0.03 & 0.08 & 0.16 & 0.29 & 0.11 & 1.00 & & & & & & & & & & & \\
\hline 7. Exploitative innovation strategy (index) & 0.09 & 0.07 & -0.01 & 0.16 & -0.10 & 0.36 & 1.00 & & & & & & & & & & \\
\hline 8. Share exports of sales (ratio) & 0.20 & 0.22 & 0.13 & 0.36 & 0.02 & 0.17 & 0.14 & 1.00 & & & & & & & & & \\
\hline 9. No of employees $(\log )$ & 0.27 & 0.34 & -0.19 & 0.23 & -0.26 & 0.05 & 0.20 & 0.29 & 1.00 & & & & & & & & \\
\hline 10. Process innovator & 0.03 & -0.01 & -0.11 & -0.07 & -0.12 & -0.11 & 0.19 & -0.04 & 0.13 & 1.00 & & & & & & & \\
\hline 11. Medium high-tech manuf. (d) & 0.09 & 0.08 & 0.06 & 0.22 & -0.01 & 0.10 & 0.08 & 0.35 & 0.12 & -0.08 & 1.00 & & & & & & \\
\hline 12. High-tech manuf. (d) & 0.04 & 0.07 & 0.20 & 0.20 & 0.09 & 0.10 & 0.05 & 0.13 & 0.00 & -0.04 & -0.18 & 1.00 & & & & & \\
\hline 13. Distributive services (d) & -0.01 & -0.03 & -0.13 & -0.18 & -0.13 & -0.09 & -0.02 & -0.15 & -0.03 & 0.02 & -0.15 & -0.11 & 1.00 & & & & \\
\hline 14. Knowledge-intens. services (d) & -0.03 & -0.05 & -0.11 & -0.16 & 0.01 & -0.07 & -0.06 & -0.23 & 0.03 & 0.04 & -0.15 & -0.10 & -0.09 & 1.00 & & & \\
\hline 15. Technological services (d) & -0.09 & -0.06 & 0.25 & 0.04 & 0.53 & -0.01 & -0.16 & -0.15 & -0.27 & -0.07 & -0.19 & -0.14 & -0.12 & -0.11 & 1.00 & & \\
\hline 16. Strength of state in business R\&D intensity (index) & 0.06 & 0.05 & 0.08 & 0.06 & 0.12 & 0.04 & 0.03 & 0.05 & 0.04 & -0.02 & 0.00 & 0.02 & -0.02 & 0.01 & 0.12 & 1.00 & \\
\hline 17. Strength of German industry R\&D intens. by OECD 2003 (index) & 0.09 & 0.08 & 0.04 & 0.16 & -0.08 & 0.05 & 0.11 & 0.26 & 0.14 & -0.02 & 0.56 & 0.03 & -0.08 & -0.17 & -0.27 & 0.00 & 1.00 \\
\hline Mean & 0.11 & 0.13 & 0.04 & 0.43 & 0.21 & 0.65 & 0.49 & 0.21 & 4.30 & 0.67 & 0.20 & 0.11 & 0.08 & 0.08 & 0.13 & 0.31 & 0.18 \\
\hline Standard deviation & 0.31 & 0.33 & 0.08 & 0.49 & 0.23 & 0.29 & 0.24 & 0.26 & 1.56 & 0.47 & 0.40 & 0.31 & 0.28 & 0.27 & 0.34 & 1.98 & 0.67 \\
\hline Min & 0.00 & 0.00 & 0.00 & 0.00 & 0.00 & 0.00 & 0.00 & 0.00 & 1.61 & 0.00 & 0.00 & 0.00 & 0.00 & 0.00 & 0.00 & -1.22 & -0.92 \\
\hline Max & 1.00 & 1.00 & 0.75 & 1.00 & 1.00 & 1.00 & 1.00 & 1.00 & 8.90 & 1.00 & 1.00 & 1.00 & 1.00 & 1.00 & 1.00 & 1.15 & 3.98 \\
\hline VIF & 1.21 & 1.28 & 1.39 & 1.50 & 1.71 & 1.29 & 1.29 & 1.47 & 1.60 & 1.11 & 1.80 & 1.31 & 1.14 & 1.22 & 1.86 & 1.04 & 1.57 \\
\hline Mean VIF & \multicolumn{17}{|l|}{1.40} \\
\hline
\end{tabular}


Appendix C: Industry breakdown

\begin{tabular}{|c|c|c|}
\hline Industry & NACE Code & Industry Group \\
\hline Mining and quarrying & $10-14$ & Other manufacturing \\
\hline Food and tobacco & $15-16$ & Other manufacturing \\
\hline Textiles and leather & $17-19$ & Other manufacturing \\
\hline Wood / paper / publishing & $20-22$ & Other manufacturing \\
\hline Chemicals / petroleum & $23-24$ & $\begin{array}{l}\text { Medium high-tech } \\
\text { manufacturing }\end{array}$ \\
\hline Plastic / rubber & 25 & Other manufacturing \\
\hline Glass / ceramics & 26 & Other manufacturing \\
\hline Metal & $27-28$ & Other manufacturing \\
\hline $\begin{array}{l}\text { Manufacture of machinery and } \\
\text { equipment }\end{array}$ & 29 & $\begin{array}{l}\text { Medium high-tech } \\
\text { manufacturing }\end{array}$ \\
\hline Manufacture of electrical machinery & $30-32$ & High-tech manufacturing \\
\hline $\begin{array}{l}\text { Medical, precision and optical } \\
\text { instruments }\end{array}$ & 33 & High-tech manufacturing \\
\hline Manufacture of motor vehicles & $34-35$ & $\begin{array}{l}\text { Medium high-tech } \\
\text { manufacturing }\end{array}$ \\
\hline $\begin{array}{l}\text { Manufacture of furniture, jewellery, } \\
\text { sports equipment and toys }\end{array}$ & $36-37$ & Other manufacturing \\
\hline Electricity, gas and water supply & $40-41$ & Other manufacturing \\
\hline Construction & 45 & Other manufacturing \\
\hline Retail and motor trade & 50,52 & Distributive services \\
\hline Wholesale trade & 51 & Distributive services \\
\hline Transportation and communication & $60-63,64.1$ & Distributive services \\
\hline Financial intermediation & $65-67$ & $\begin{array}{l}\text { Knowledge-intensive } \\
\text { services }\end{array}$ \\
\hline Real estate activities and renting & $70-71$ & Distributive services \\
\hline ICT services & $72,64.2$ & Technological services \\
\hline Technical services & $73,74.2,74.3$ & Technological services \\
\hline Consulting & $74.1,74.4$ & $\begin{array}{l}\text { Knowledge-intensive } \\
\text { services }\end{array}$ \\
\hline Other business-oriented services & $74.5-74.8,90$ & Distributive services \\
\hline
\end{tabular}

Appendix D: Smith-Satherwaite Test

$$
\begin{aligned}
& t=\frac{x_{1}-x_{2}}{\sqrt{\left(s_{1}^{2} / n_{1}\right)+\left(s_{2}^{2} / n_{2}\right)}} \\
& d f=\frac{\left(\left(s_{1}^{2} / n_{1}\right)+\left(s_{2}^{2} / n_{2}\right)\right)^{2}}{\left(s_{1}^{2} / n_{1}\right)^{2} /\left(n_{1}-1\right)+\left(s_{2}^{2} / n_{2}\right)^{2} /\left(n_{2}-1\right)}
\end{aligned}
$$

where: $x_{1}=$ mean of sample (group) 1

$x_{2}=$ mean of sample (group) 2

$s_{1}=$ standard deviation of sample 1

$s_{2}=$ standard deviation of sample 2

$n_{1}=$ size of sample 1

$n_{2}=$ size of sample 2 .

The degrees of freedom are rounded off to the next highest whole number. 